\title{
ПЛАНУВАННЯ НА ОСНОВІ СПРОМОЖНОСТЕЙ: НОВА ПАРАДИГМА РОЗВИТКУ МЕДИЧНИХ СИЛ ЗБРОЙНИХ СИЛ УКРАЇНИ
}

\author{
В.О. Жаховський, В.Г. Лівінський
}

\author{
Украӥнська військово-медична академія, м. Київ, Україна
}

\begin{abstract}
Мета роботи - аналіз та узагальнення процесів розвитку Медичних сил Збройних Сил України (Медичні сили) через запровадження планування їх розвитку на основі спроможностей.

Матеріали та методи. Використано доктринальні документи з питань національної безпеки $i$ оборони України, керівні документи Міністерства оборони (МО) України та Збройних Сил (ЗС) України, публікації у періодичних наукових виданнях. Об'єкт дослідження - Медичні сили ЗС України. Предмет дослідження - планування розвитку Медичних сил на основі спроможностей. Методи дослідження: бібліографічний, системного підходу, аналітичний, узагальнення.

Результати. У статті розглянуто вимоги доктринальних документів з питань національної безпеки і оборони України, керівних документів МО України та ЗС України щодо впровадження в практику оборонного планування в Україні планування на основі спроможностей. Висвітлено переваги оборонного планування на основі спроможностей, його етапи та порядок проведення. Наведено методичні підходи до формування переліку спроможностей, переліку носіїв спроможностей, а також опису спроможностей Медичних сил та їх носіїв. Приведено алгоритм дій щодо проведення оцінювання спроможностей Медичних сил в ході оборонного огляду та їх розвитку.

Висновки. Розвиток ЗС України здійснюється в напрямку досягнення сумісності зі збройними силами держав-членів НАТО шляхом планування їх розвитку на основі спроможностей. Планування розвитку Медичних сил на основі спроможностей передбачає здійснення аналізу завдань та функцій Медичних сил в імовірних варіантах застосування ЗС України, що трансформуються у вимоги до спроможностей, на підставі чого планується їх створення, утримання та розвиток.
\end{abstract}

Ключові слова: оборонне планування, планування на основі спроможностей, спроможності Медичних сил.

Вступ. Двадцять четвертого вересня 2015 року відповідним Указом Президента України затверджено нову редакцію Воєнної доктрини України [1]. Цим документом встановлено, що розвиток Збройних Сил (3С) України здійснюватиметься за західними стандартами в напрямку досягнення сумісності зі збройними силами держав-членів НАТО. Одним із шляхів досягнення цілей воєнної політики України визначено формування національних оборонних спроможностей через упровадження прийнятих у НАТО стандартів бюджетного планування.

В Концепції розвитку сектору безпеки i оборони України [2] сформульовано основну мету та завдання розвитку сектору безпеки $\mathrm{i}$ оборони, тобто формування та підтримання спроможностей, що дадуть змогу гарантовано забезпечити адекватне і гнучке реагування на весь спектр загроз національній безпеці України, раціонально використовуючи наявні у державі можливості та ресурси, шляхом запровадження системи планування на основі спроможностей у всіх складових сектору безпеки i оборони, узгоджуючи цей процес з програмно-цільовим та іншими сучасними методами планування фінансових та інших матеріально-технічних ресурсів.
Відповідно до військового стандарту «Воєнна безпека. Стратегічне планування. Терміни та визначення.» [3] планування сил на основі спроможностей передбачає:

визначення вимог до спроможностей;

уточнення необхідних спроможностей 3С України за імовірними сценаріями їх застосування, розвиток яких потребує планування на середньострокову і довгострокову перспективи та формування їх переліку;

визначення недостатніх спроможностей, які підлягають створенню, а також існуючих спроможностей, які необхідно розвивати;

визначення надлишкових спроможностей, від яких необхідно позбавитись 3 метою вивільнення ресурсів.

За результатами проведеного оборонного огляду указом Президента України затверджено Стратегічний оборонний бюлетень України [4], в якому визначено мету і стратегічні цілі оборонної реформи, у тому числі й для розвитку медичного забезпечення Сил оборони (оперативна ціль 4.2).

3 метою визначення єдиних підходів та деталізації процесів з оборонного планування на основі спроможностей в Міністерстві оборони (M0) України розроблено та затверджено «Рекомендації 3 оборонного планування на 
основі спроможностей в Міністерстві оборони України та Збройних Силах України» [5] та «Рекомендації з порядку організації проведення оцінювання спроможностей у Збройних Силах України» [6], на основі яких відповідно до принципів та методології євроатлантичних держав, 3 урахуванням особливостей вітчизняного оборонного відомства та ЗС України, на підставі моделі Каталогу НАТО розроблено Єдиний Перелік (Каталог) спроможностей МО України та ЗС України. Спроможності системи медичного забезпечення 3С України віднесено до функціональної групи «Забезпечення».

Ці інновації не оминули уваги як керівників оборонного відомства, так і науковців. В статті «Оборонне планування на основі спроможностей: особливості та перспективи впровадження» [7] Руснак I.C. та співавтори розкривають переваги оборонного планування на основі спроможностей, його етапи та порядок проведення. Бадюк М.I та співавтори аналізують порядок організації та проведення оцінки спроможностей медичної служби 3С України $[8,9]$, що $є$ одним із наступних етапів загального процесу планування на основі спроможностей.

Водночас загальні підходи до планування розвитку медичної служби (на цей час Медичних сил Збройних Сил України) на основі спроможностей, формування переліку спроможностей, переліку носіїв спроможностей, а також опису цих спроможностей та їх носіїв досі не проводилися і не оприлюднювалися.

Мета роботи. Аналіз і узагальнення процесів розвитку Медичних сил Збройних Сил України (Медичні сили) через запровадження планування їх розвитку на основі спроможностей.

Матеріали та методи дослідження. Використано доктринальні документи з питань національної безпеки і оборони України, керівні документи МО України та ЗС України, публікації у періодичних наукових виданнях. Методи дослідження: бібліографічний, системного підходу, аналітичний, узагальнення.

Результати дослідження та їх обговорення. Відповідно до вимог розроблених та прийнятих у МО України організаційнометодичних документів $[5,6]$ оборонне планування на основі спроможностей передбачає в системі медичного забезпечення ЗС України здійснення аналізу завдань і функцій Медичних сил в імовірних варіантах застосування ЗС України, що трансформуються у вимоги до спроможностей, на підставі чого планується їх створення, утримання та розвиток. Як результат передбачається створення, розвиток та підтримання оптимального складу необхідних спроможностей Медичних сил у межах наявних ресурсів. Водночас матеріальні ресурси не завжди $\epsilon$ визначальним фактором розвитку спроможностей. Ефективними шляхами їх нарощування $\epsilon$ також удосконалення доктринальної бази медичного забезпечення військ (сил), формування структур органів управління медичним забезпеченням, військовомедичних закладів і медичних підрозділів військових частин, впровадження нових організаційних засад, методів і методик надання медичної допомоги, покращення системи відбору, навчання, підготовки та мотивації медичного персоналу тощо.

3 метою єдиного методологічного підходу до формування переліку спроможностей Медичних сил, переліку носіїв спроможностей, а також опису цих спроможностей та їх носіїв встановлені базові компоненти (складові) спроможностей, які $\epsilon$ визначальними для їх створення, розвитку та оцінювання. До них відносяться:

доктринальна база - наявність концепцій, доктрин, настанов, керівництв, інструкцій та інших керівних документів з питань військової охорони здоров'я;

організація - наявність необхідної організаційної структури відповідних сил i засобів, які створюють відповідну спроможність;

підготовка - наявність системи підготовки відповідних сил і засобів, що створюють певну спроможність, індивідуальна та колективна підготовка особового складу, підготовка органів управління та військово-медичних закладів;

ресурсне забезпечення - забезпеченість необхідним комплектно-табельним оснащенням, медичною апаратурою і технікою, санітарнотранспортними засобами, спеціальною медичною технікою та сучасним санітарнотехнічним обладнанням модульного типу, запасами матеріально-технічних засобів i витратних матеріалів, а також фінансовими ресурсами;

якість управління та освіта - наявність належного рівня професійної підготовки керівного складу Медичних сил в органах управління та на всіх рівнях медичного забезпечення, системи військово-медичної освіти і науки, яка забезпечує обгрунтований розвиток Медичних сил та якісне медичне забезпечення 3С України у всіх варіантах їх застосування;

персонал - наявність кваліфікованого та мотивованого особового складу; 
військова інфраструктура - наявність об'єктів та окремих споруд, призначених для розміщення медичних підрозділів військових частин i військово-медичних закладів для забезпечення їх життєдіяльності та належного функціонування в стаціонарних і польових умовах;

сумісність - доктринальна, технічна та процедурна сумісність сил і засобів Медичних сил для спільних дій під час медичного забезпечення військ (сил) у складі Сил оборони, а також багатонаціональних формувань.

Основою для формування каталогу (переліку) спроможностей як ЗС України загалом, так i для Медичних сил, $\epsilon$ існуючі вимоги законодавства, нормативно-правових актів України та керівних документів МО України і Генерального штабу (ГШ) ЗС України щодо підготовки та застосування органів управління медичним забезпеченням, медичних підрозділів військових частин і військово-медичних закладів, а також їх всебічного забезпечення.

Таким чином, на думку авторів та відповідно до військового стандарту «Воєнна безпека. Стратегічне планування. Терміни та визначення.» [3], спроможність Медичних сил це здатність органів управління медичним забезпеченням, медичних підрозділів військових частин, санітарно-транспортних підрозділів i військово-медичних закладів здійснювати медичне забезпечення ЗС України як в мирний час, так і в умовах особливого періоду за певних умов, ресурсного забезпечення та відповідно до встановлених медичних стандартів (стандартів медичної допомоги) і військово-медичних стандартів.

Кожний орган управління медичним забезпеченням, кожний медичний підрозділ військової частини або військово-медичний заклад Медичних сил може мати більш ніж одну спроможність, а кожна спроможність може реалізовуватися більш ніж одним носієм спроможностей.

Протягом 2019 року авторами були опрацьовані та встановленим порядком передані на розгляд посадових осіб Головного військовомедичного управління перелік спроможностей медичної служби (на цей час - Медичних сил 3С України), перелік носіїв спроможностей, а також опис цих спроможностей та їх носіїв.

До переліку спроможностей Медичних сил включено 48 спроможностей, які функціонально об’єднані у 8 типових груп, а саме:

планування медичного забезпечення

(5 кодів спроможностей);

організація медичного забезпечення (7 кодів спроможностей);

управління медичним забезпеченням

(6 кодів спроможностей);

здійснення медичного забезпечення

(15 кодів спроможностей);

проведення санітарно-гігієнічних та

протиепідемічних заходів (3) коди

спроможностей);

медичне постачання (медична логістика)

(6 кодів спроможностей);

підготовка, перепідготовка і підвищення кваліфікації медичного персоналу, його раціональне використання та наукове вирішення проблем медичного забезпечення військ (4 коди спроможностей);

військово-медична підготовка особового складу військ, пропаганда гігієнічних знань та здорового способу життя (2 коди спроможностей).

Формування опису спроможностей Медичних сил передбачало присвоєння кожній типовій групі спроможностей, а також кожній спроможності відповідного коду в рамках функціональної групи «Забезпечення», визначення переліку законодавчих, нормативноправових актів України та керівних документів МО України і ГШ ЗС України щодо підготовки та застосування органів управління медичним забезпеченням, медичних підрозділів військових частин і військово-медичних закладів, а також їх всебічного забезпечення, загальний опис типової групи спроможностей, основні та додаткові вимоги до спроможності (перелік умов, критеріїв та показників виконання завдань за призначенням, що містяться в ситуаціях за сценаріями застосування ЗС України та в законодавчих, нормативно-правових актах України і керівних документах).

Відповідно до вимог організаційнометодичних документів МО України $[5,6]$ авторами запропоновано вносити до каталогу (переліку) спроможностей 3С України для Медичних сил такі основні типи носіїв спроможностей:

органи управління медичним забезпеченням стратегічного, оперативного та тактичного рівнів;

медичні підрозділи військових частин i військово-медичні заклади;

окремі засоби - санітарно-транспортні засоби, у тому числі для наземної, повітряної та морської (водної) медичної евакуації.

До переліку носіїв спроможностей Медичних сил включено 48 організаційних структур, які функціонально об'єднані у 12 типових груп, а саме: 
орган управління медичним забезпеченням стратегічного рівня (1 код носія спроможності);

служба превентивної медицини (2 коди носія спроможності);

медичні служби видів, родів військ (сил)

(5 кодів носія спроможності);

медичні служби ОК і ПвК видів, родів військ

(сил) (2 коди носія спроможності);

медичні служби військових частин та ВВНЗ

(4 коди носія спроможності);

лікувально-профілактичні заклади (4 коди

носія спроможності);

санаторно-курортні заклади (3 коди носія

спроможності);

заклади медичного постачання (3 коди носія

спроможності);

навчальні заклади та навчальні підрозділи

(3 коди носія спроможності);

інші військово-медичні заклади (3 коди носія

спроможності);

медичні підрозділи військових частин, ВВНЗ

(5 кодів носія спроможності);

підрозділи та засоби медичної евакуації (5 кодів носія спроможності).

Під час формування опису носіїв спроможностей Медичних сил кожній типовій групі носіїв спроможностей, а також кожному носію спроможностей присвоєно відповідний код, визначено перелік законодавчих i нормативно-правових актів України та керівних документів МО України, якими вони керуються під час виконання завдань за призначенням, а також описані базові, основні та додаткові вимоги до носія спроможності.

Таким чином, на цей час опрацьовано та завершено початкові етапи планування розвитку Медичних сил на основі спроможностей. У подальшому організаційно-методичними документами МО України $[5,6]$ передбачено проведення періодичних оглядів та оцінювання спроможностей 3С України, у тому числі i Медичних сил, як цілеспрямованого i організованого процесу перевірки об'єктів оцінювання з метою визначення їх готовності до виконання завдань за призначенням. Під час проведення оцінювання спроможності класифікуються як необхідні, наявні, критичні та надлишкові.

Необхідні спроможності - ті, що повинні бути у розпорядженні відповідного начальника органу управління медичним забезпеченням (начальника медичної служби) у визначений час та місці, для виконання завдань у певних умовах середовища 3 необхідним результатом (ефектом).

Наявні спроможності - це ті спроможності, що $є$ у розпорядженні відповідного начальника органу управління медичним забезпеченням (начальника медичної служби) для виконання завдань, але вони можуть виявитися недостатніми для досягнення необхідного результату (ефекту).

Критичні спроможності - ті спроможності, що $\epsilon$ абсолютно важливими для досягнення необхідного результату (ефекту) відповідною структурою та потребують створення (розвитку) та утримання у пріоритетному порядку.

Оцінювання наявних спроможностей Медичних сил здійснюється за методиками і процедурою, що встановлені «Рекомендаціями 3 порядку організації проведення оцінювання спроможностей у Збройних Силах України» [6] в ході оборонного огляду та огляду спроможностей (1 раз на 2-3 роки за рішенням Міністра оборони України), а також за необхідністю. Воно здійснюється за усіма базовими компонентами (складовими) спроможностей та передбачає оцінювання:

- чинних доктринальних документів, які застосовуються щодо підготовки, застосування та організації повсякденної діяльності органу управління медичним забезпеченням, медичного підрозділу військової частини або військовомедичного закладу тощо;

- організаційної структури та складу наявних органів управління медичним забезпеченням, медичних підрозділів військових частин і військово-медичних закладів щодо їх здатності виконувати завдання за призначенням з необхідним рівнем ефективності;

- рівня підготовки особового складу до виконання завдань за призначенням;

- забезпеченості необхідними зразками комплектно-табельного оснащення, медичною апаратурою i технікою, санітарнотранспортними засобами, спеціальною медичною технікою та сучасним санітарнотехнічним обладнанням для виконання завдань за призначенням, з урахуванням їх технічного стану і термінів експлуатації;

- стану та здатності системи матеріальнотехнічного забезпечення (логістики) Медичних сил до виконання завдань за призначенням, у тому числі наявність необхідних запасів;

- якості військово-медичної освіти та науки, її здатності забезпечити належний рівень професійної підготовки особового складу i обгрунтування розвитку Медичних сил;

- наявності кваліфікованого та мотивованого військового i цивільного медичного персоналу;

- наявної військової інфраструктури для 
розміщення медичних підрозділів військових частин і військово-медичних закладів, іiї здатності забезпечувати їх життєдіяльність і функціонування та виконання ними завдань за призначенням;

- рівня сумісності 3 відповідними підрозділами збройних сил держав-членів НATO.

Для нормативного забезпечення організації процесу оцінювання спроможностей «Доктриною 3 організації оцінювання (сертифікації) у Збройних Силах України» [10] передбачено опрацювання у кожному виді (роді) військ (сил) ЗС України відповідної інструкції, у тому числі і в Медичних силах - «Інструкції 3 оцінювання (сертифікації) оперативних (бойових, спеціальних) спроможностей в Медичних силах Збройних Сил України».

За результатами оцінювання спроможностей приймається рішення щодо утримання наявних спроможностей або їх нарощування (модернізації), формування нових спроможностей, а також позбавлення від надлишкових спроможностей.

Утримання наявних спроможностей включає проведення заходів за визначеними ï базовими компонентами (складовими) 3 метою забезпечення необхідного стану та здатності наявних сил і засобів виконувати завдання за призначенням.

Нарощування (модернізація) наявних спроможностей означає поповнення їх існуючими силами та засобами 3 метою досягнення амбіційного рівня спроможностей для виконання завдань за призначенням. При цьому можливі якісні зміни в оснащенні медичних підрозділів військових частин і військово-медичних закладів, удосконалення їх структури.

Формування нових спроможностей, як правило, вимагає створення нових організаційних структур або переформування існуючих, нового комплектно-табельного оснащення, медичної апаратури і техніки, санітарно-транспортних засобів, спеціальної медичної техніки та сучасного санітарнотехнічного обладнання, впровадження новітніх методів і методик надання медичної допомоги тощо для виконання завдань за призначенням.

Позбавлення від надлишкових спроможностей передбачає вивільнення Медичних сил від виконання окремих функцій; скорочення та оптимізацію організаційної структури медичних підрозділів військових частин і військовомедичних закладів, а також органів управління медичним забезпеченням, в яких немає потреби.

Повний цикл розвитку Медичних сил шляхом запровадження планування на основі спроможностей наведено на рисунку.

Таким чином, формування переліку спроможностей Медичних сил, переліку носіїв спроможностей, опис цих спроможностей та їх носіїв i проведення їх оцінювання не $\epsilon$ самоціллю, а $\epsilon$ лише інструментом для подальшого розвитку Медичних сил задля забезпечення їхніх спроможностей до медичного забезпечення ЗС України в усіх варіантах та сценаріях їх застосування.

За результатами проведення оборонного огляду та оцінювання спроможностей передбачено розроблення ГШ ЗС України комплексного документу 3 розвитку спроможностей $3 \mathrm{C}$ України, яким визначатимуться етапи досягнення перспективних спроможностей перспективним складом 3С України, у тому числі й Медичними силами, а також конкретні кроки для досягнення цих необхідних спроможностей [6]. За необхідності для його реалізації розроблятимуться державні цільові програми, спрямовані на розв'язання проблем у сфері оборони держави, у тому числі з питань військової охорони здоров'я.

Планування розвитку Медичних сил здійснюється на основі варіантів застосування ЗС України і включає:

визначення необхідних спроможностей Медичних сил для виконання завдань за варіантами застосування ЗС України;

оцінювання наявних спроможностей та їх відповідності до здатності виконання завдань за призначенням;

визначення недостатніх та надлишкових спроможностей шляхом порівняння необхідних та наявних спроможностей;

планування заходів з утримання наявних, формування недостатніх та позбавлення від надлишкових спроможностей.

Таким чином, на цей час у МО України та 3С України розпочато та проводиться планування розвитку ЗС України, у тому числі Медичних сил, на основі спроможностей, що $\epsilon$ вагомим та значним кроком у напрямку досягнення сумісності зі збройними силами держав-членів НАТО. 


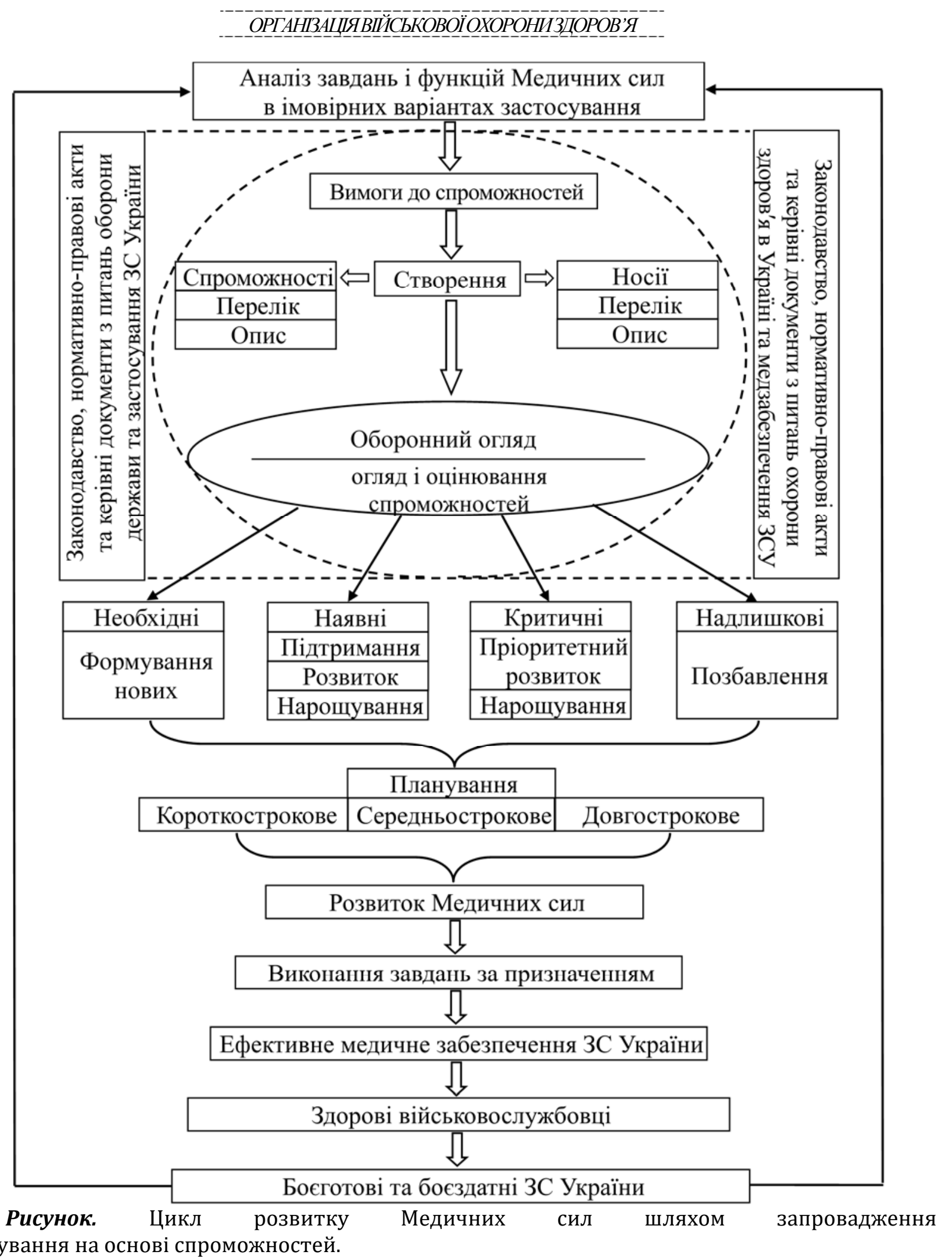
планування на основі спроможностей.

\section{Висновки}

1. Розвиток 3С України за західними стандартами в напрямку досягнення сумісності зі збройними силами держав-членів НАТО передбачає формування національних оборонних спроможностей через впровадження прийнятих у НАТО стандартів бюджетного планування.

2. Оборонне планування на основі спроможностей передбачає здійснення аналізу завдань та функцій Медичних сил в імовірних варіантах застосування $3 \mathrm{C}$ України, що трансформуються у відповідні вимоги до спроможностей, на підставі чого планується їх створення, утримання та розвиток. Як результат, передбачається створення, розвиток та підтримання оптимального складу необхідних спроможностей Медичних сил у межах наявних ресурсів. 
3. Формування переліку спроможностей Медичних сил, переліку носіїв спроможностей, опис цих спроможностей та їх носіїв, а також проведення їх оцінювання не $\epsilon$ самоціллю, а $\epsilon$ лише інструментом для подальшого розвитку

\section{Література}

1. Указ Президента України від 24 вересня 2015 року № 555/2015 «Про рішення Ради національної безпеки і оборони України від 2 вересня 2015 року «Про нову редакцію Воєнної доктрини України».

2. Указ Президента України від 14 березня 2016 року № 92/2016 «Про рішення Ради національної безпеки і оборони України від 4 березня 2016 року «Про Концепцію розвитку сектору безпеки і оборони України».

3. Військовий стандарт ВСТ 01.004.002 - 2019 (02) (Видання 2) «Воєнна безпека. Стратегічне планування. Терміни та визначення.» К. : МО України, 2019.

4. Указ Президента України від 6 червня 2016 року № 240/2016 «Про рішення Ради національної безпеки і оборони України від 20 травня 2016 року «Про Стратегічний оборонний бюлетень України».

5. Рекомендації з оборонного планування на основі спроможностей в Міністерстві оборони України та Збройних Силах України / Затверджені Міністром оборони України, 12.06.2017. Міністерство оборони України. - К.: МО України, 2017.

6. Рекомендації з порядку організації проведення оцінювання спроможностей у Збройних Силах України

\section{References}

1. Decree of the President of Ukraine of September 24, 2015 № 555/2015 "On the decision of the National Security and Defense Council of Ukraine of September 2, 2015" On the new version of the Military Doctrine of Ukraine ".

2. Decree of the President of Ukraine of March 14, 2016 № 92/2016 "On the decision of the National Security and Defense Council of Ukraine of March 4, 2016" On the Concept of Development of the Security and Defense Sector of Ukraine "https://zakon.rada.gov.ua/laws/show192/2016\#Text

3. Military standard VST 01.004.002 - 2019 (02) (Edition 2) "Military security. Strategic planning. Terms and definitions. " - Kyiv: Ministry of Defense of Ukraine, 2019.

4. Decree of the President of Ukraine of June 6, 2016 № 240/2016 "On the decision of the National Security and Defense Council of Ukraine of May 20, 2016" On the Strategic Defense Bulletin of Ukraine ". https://zakon.rada.gov.ua/laws/show/240/2016\#Text

5. Recommendations on defense planning based on capabilities in the Ministry of Defense of Ukraine and the Armed Forces of Ukraine (2017). Approved by the Minister of Defense of Ukraine, 06/12/2017. Ministry of Defense of Ukraine. - Kyiv: Ministry of Defense of Ukraine.
Медичних сил задля забезпечення їх спроможності до медичного забезпечення 3С України у всіх варіантах та сценаріях застосування.

/ Затверджені Міністром оборони України, 07.12.2017. Міністерство оборони України. - К.: МО України, 2017.

7. Руснак I.C. Оборонне планування на основі спроможностей: особливості та перспективи впровадження / I.C. Руснак, А.Г. Петренко, А.В. Яковенко, І.М. Романюк, В.Д. Кохно. «Наука $i$ оборона». 2017. № 2. С. 3-10.

8. Бадюк M.I. Сучасні погляди на організацію та проведення оцінки спроможностей медичної служби Збройних Сил України / M.I. Бадюк, О.О. Микита, А.М. Губар, Є.О. Зуй, І.К. Середа. Військова медицина України. 2019. Том 19 1. С. 5-10.

9. Бадюк М.I. Сучасні погляди на організацію та оцінювання спроможностей медичної служби Збройних Сил України / М.І. Бадюк, Є.О. Зуй, А.М. Губар // Наукова конференція молодих вчених 27-28 травня 2019 року: Тези доповідей. Ч.1. К: УВМА, 2019. 120 с.

10. Доктрина 3 організації оцінювання (сертифікації) у Збройних Силах України / Затверджена Начальником Генерального штабу Збройних Сил України, 30.06.2020 // ВКП 7-00(03).01.

6. Recommendations on the organization of capability assessment in the Armed Forces of Ukraine (2017). Approved by the Minister of Defense of Ukraine, 07.12.2017.Ministry of Defense of Ukraine. - Kyiv: Ministry of Defense of Ukraine.

7. Rusnak, I.S. Petrenko, A.G., Yakovenko, A.B., Romanyuk, I.M, Kohno, V.D. (2017). Defense planning based on capabilities: features and prospects of implementation. Journal "Science and Defense". № 2. 3-10.

8. Badyuk, M.I., Mikita, O.O., Gubar, A.M., Zui, Ye.O., Sereda, I.K. (2019). Modern views on the organization and evaluation of the capabilities of the medical service of the Armed Forces of Ukraine. Military Medicine of Ukraine. V.19 (1). 5-10.

9. Badyuk, M.I., Zui, Ye.O., Gubar, A.M. (2019). Modern views on the organization and evaluation of the capabilities of the medical service of the Armed Forces of Ukraine. Scientific Conference of Young Scientists May 27-28: Abstracts. Part 1. UMMA. 120.

10. Doctrine on the organization of assessment (certification) in the Armed Forces of Ukraine (2020). Approved by the Chief of the General Staff of the Armed Forces of Ukraine, 30.06.2020. VKP 7-00 (03) 01. 


\title{
ПЛАНИРОВАНИЕ НА ОСНОВЕ СПОСОБНОСТЕЙ: НОВАЯ ПАРАДИГМА РАЗВИТИЯ МЕДИЦИНСКИХ СИЛ ВООРУЖЕННЫХ СИЛ УКРАИНЫ
}

\author{
В.А. Жаховский, В.Г. Ливинский
}

Украинская военно-медицинская академия, г. Киев, Украина

\begin{abstract}
Цель работы - анализ и обобщение процессов развития Медицинских сил Вооруженных Сил Украины (Медицинские силы) из-за введения планирования их развития на основе способностей.

Материалы и методы. Использованы доктринальные документы по вопросам национальной безопасности и обороны Украины, руководящие документы Министерства обороны (МО) Украины и Вооруженных Сил (BC) Украины, публикации в периодических научных изданиях. Объект исследования Медицинские силы ВС Украины. Предмет исследования - планирование развития Медицинских сил на основе способностей. Методы исследования: библиографический, системного подхода, аналитический, обобщения.

Результаты. $B$ статье рассмотрены требования доктринальных документов по вопросам национальной безопасности и обороны Украины, руководящих документов МО Украины и ВС Украины по внедрению в практику оборонного планирования в Украине планирования на основе способностей. Освещены преимущества оборонного планирования на основе способностей, его этапы и порядок проведения. Приведены методические подходы к формированию перечня способностей, перечень носителей способностей, а также описания способностей Медицинских сил и их носителей. Приведены алгоритм действий по проведению оценки способностей Медицинских сил в ходе оборонного обзора и их развития.

Выводы. Развитие ВC Украины осуществляется в направлении достижения совместимости с вооруженными силами государств-членов НАТО путем планирования их развития на основе способностей. Планирование развития Медицинских сил на основе способностей предусматривает осуществление анализа задач и функций Медицинских сил в возможных вариантах применения ВС Украины, что трансформируется в требования к способностям, на основании чего планируется их создание, содержание и развитие.
\end{abstract}

Ключевые слова: оборонное планирование, планирование на основе способностей, способности Медицинских сил.

\section{CAPABILITY-BASED PLANNING: A NEW PARADIGM FOR THE DEVELOPMENT OF THE MEDICAL FORCES OF THE ARMED FORCES OF UKRAINE}

\section{V.o. Zhahovskiy, V.G. Livinskiy}

Ukrainian military medical academy, Kyiv, Ukraine

The purpose of the work is analysis and generalization of the processes of development of the Medical Forces of the Armed Forces of Ukraine (Medical Forces) through the introduction of planning their development on the basis of capabilities.

Materials and methods. Doctrinal documents on national security and defense of Ukraine, guiding documents of the Ministry of Defense (MoD) of Ukraine and the Armed Forces (AF) of Ukraine, publications in scientific periodicals were used. The object of research is the Medical Forces of the Armed Forces of Ukraine. The subject of research - planning the development of medical forces on the basis of capabilities. Research methods: bibliographic, systems approach, analytical, generalization.

Results. The article considers the requirements of doctrinal documents on national security and defense of Ukraine, guiding documents of the Ministry of Defense of Ukraine and the Armed Forces of Ukraine on the implementation of defense-based planning in Ukraine. The advantages of capability-based defense planning, its stages and procedure are highlighted. Methodical approaches to the formation of the list of capabilities, the list of capacity carriers, as well as the description of the capabilities of the Medical Forces and their carriers have been given. An algorithm of actions for assessing the capabilities of the Medical Forces during the defense review and their development is given.

Conclusions. The development of the Armed Forces of Ukraine is aimed at achieving compatibility with the armed forces of NATO member states by planning their development on the basis of capabilities. Capacity-based development of the Medical Forces involves the analysis of the tasks and functions of the Medical Forces in the probable applications of the Armed Forces of Ukraine, which are transformed into capabilities requirements, based on which their creation, maintenance and development are planned.

Key words: defense planning, capability-based planning, capabilities of the Medical Forces.

Конфлікт інтересів: відсутній.

Conflicts of interest: authors have no conflict of interest to declare. 


\section{Відомості про авторів:}

Жаховський B.O. A,B,C,D,E,F - кандидат наук з державного управління, Науково-дослідний інститут проблем військової медицини Української військово-медичної академії, провідний науковий співробітник науково-дослідного відділу організації медичного забезпечення, https://orcid.org/00000002-2665-2766, Email: zhahovskiy-viktor@ukr.net, 01015, м. Київ, вул. Московська, 45/1, тел./факс: $0442800143,0675767547$.

Лівінський В.Г. A,B,C,D,E,F - кандидат медичних наук, Науково-дослідний інститут проблем військової медицини Української військово-медичної академії, провідний науковий співробітник науково-дослідного відділу медичної стандартизації та метрологічного забезпечення, https://orcid.org/0000-0002-1102-1128, Email: v.livinskiy@gmail.com, 01015, м. Київ, вул. Московська, 45/1, тел./факс: 04428001 43, 0674534448.

$A$ - концепція та дизайн дослідження; $B$ - збір даних; $C$ - аналіз та інтерпретація даних;

$D$ - написання статті; $E$ - редагування статті; F - остаточне затвердження статті.

\section{Сведения об авторах:}

Жаховский Виктор Александрович - кандидат наук государственного управления, Научноисследовательский институт проблем военной медицины Украинской военно-медицинской академии, ведущий научный сотрудник научно-исследовательского отдела организации медицинского обеспечения, https://orcid.org/0000-0002-2665-2766, Email: zhahovskiy-viktor@ukr.net, 01015, г. Киев, ул. Московская, 45/1, тел./факс: 04428001 43, 0675767547.

Ливинский Владимир Григорьевич - кандидат медицинских наук, Научно-исследовательский институт проблем военной медицины Украинской военно-медицинской академии, ведущий научный сотрудник научно-исследовательского отдела медицинской стандартизации и метрологического обеспечения, https://orcid.org/0000-0002-1102-1128, Email: v.livinskiy@gmail.com, 01015, г. Киев, ул. Московская, 45/1, тел./факс: $0442800143,0674534448$.

\section{Information about authors:}

Zhahovskiy Viktor A,B,C,D,E,F - candidate of science in public administration, Research Institute of Military Medicine of the Ukrainian Military Medical Academy, leading researcher research department organization of medical support, https://orcid.org/0000-0002-2665-2766, Email: zhahovskiy-viktor@ukr.net, 01015, Kyiv, Moskovska Street, 45/1, tel./fax: 04428001 43, 0675767547.

Livinskiy Vladimir A,B,C,D,E,F - candidate of medical sciences, Research Institute of Military Medicine of the Ukrainian Military Medical Academy, leading researcher of the research department of medical standardization and metrological support, https://orcid.org/0000-0002-1102-1128, Email: v.livinskiy@gmail.com, 01015, Kyiv, Moskovska Street, 45/1, tel./fax: 04428001 43, 0674534448.

$A$ - research concept and design; $B$ - collection and/or assembly of data; $C$ - data analysis and interpretation; $D$ - writing the article; $E$-critical revision of the article; $F$ - final approval of the article.

Адреса для листування: вул. Московська, 45/1, буд. 33, м. Київ 01015

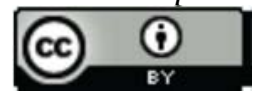

